\section{An Application of the Principles of Allometry to the Study of English Senonian Echinocorys}

THE following notes summarize the results of an investigation which was curtailed by the War, but irregular sea urchins from a given locality. The matter needs further investigation, but its effects on certain taxonomic questions may well be important.

The results are fully described in a thesis accepted by the University of London for the degree of doctor

APPROXIMATE VALUES OF GROWTH COFFFTCIENTS IN SELECTED GROUPS OF. ECHINOCORYS

\begin{tabular}{|c|c|c|c|c|c|c|}
\hline \multirow{2}{*}{ Zone } & \multirow{2}{*}{ Subdivision } & \multirow{2}{*}{ Locality } & \multicolumn{2}{|c|}{$\begin{array}{l}\text { Coeffts. of } \\
\text { relative height }\end{array}$} & \multirow{2}{*}{$\begin{array}{l}\text { Coeffit. of } \\
\text { relative } \\
\text { breadth }\end{array}$} & \multirow[b]{3}{*}{$\begin{array}{l}\text { Southern } \\
\text { England }\end{array}$} \\
\hline & & & $b$ & $a$ & & \\
\hline $\begin{array}{l}\text { M. cortestudinarium } \\
\text { M. coranguinum } \\
\text { Marsupites } \\
\text { O. pillula } \\
\text { Base, B. mucronata }\end{array}$ & $\begin{array}{l}\text { Uintacrinus } \\
\text { depressula }\end{array}$ & $\begin{array}{l}\text { Northfleet } \\
\text { Shawford }\end{array}$ & $\begin{array}{l}0 \cdot 21 \\
0 \cdot 30 \\
0 \cdot 27 \\
0 \cdot 12 \\
0 \cdot 53\end{array}$ & $\begin{array}{l}1 \cdot 35 \\
1 \cdot 20 \\
1 \cdot 25 \\
1 \cdot 45 \\
1 \cdot 10\end{array}$ & $\begin{array}{l}0 \cdot 87 \\
0 \cdot 83 \\
0 \cdot 79 \\
0 \cdot 83 \\
0 \cdot 84\end{array}$ & \\
\hline $\begin{array}{l}\text { Base, B. mucronata } \\
\text { B. mucronata } \\
\text { B. mucronata } \\
\text { Ostrea lunata } \\
\text { Ostrea lunata } \\
\text { Ostrea lunata } \\
\end{array}$ & $\begin{array}{l}\text { Sponge beds } \\
\text { Grey chalk } \\
\text { White chalk with } 0 \text {. lunata }\end{array}$ & $\begin{array}{l}\text { Bramford } \\
\text { Harford } \\
\text { Catton } \\
\text { Trimingham } \\
\text { Trimingham } \\
\text { Trimingham }\end{array}$ & $\begin{array}{l}0 \cdot 40 \\
0 \cdot 33 \\
0 \cdot 32 \\
0 \cdot 51 \\
0 \cdot 35 \\
0 \cdot 20\end{array}$ & $\begin{array}{l}1 \cdot 15 \\
1 \cdot 20 \\
1 \cdot 20 \\
1 \cdot 05 \\
1 \cdot 15 \\
1 \cdot 30\end{array}$ & $\begin{array}{l}0.86 \\
0.85 \\
0.83 \\
0.82 \\
0.85 \\
0.87\end{array}$ & East Anglia \\
\hline $\begin{array}{l}\text { Holaster planus } \\
M \text {. cortestudinarium } \\
\text { Marsupites } \\
\text { Actinocamax quadratus }\end{array}$ & . & & $\begin{array}{l}0 \cdot 68 \\
0 \cdot 64 \\
0 \cdot 08 \\
0 \cdot 38\end{array}$ & $\begin{array}{l}1 \cdot 05 \\
1 \cdot 05 \\
1 \cdot 50 \\
1 \cdot 15\end{array}$ & $\begin{array}{l}0 \cdot 88 \\
0 \cdot 89 \\
0 \cdot 79 \\
0 \cdot 88\end{array}$ & Yorkshire \\
\hline
\end{tabular}

which, though incomplete, has introduced some important conceptions. They concern the size and proportion changes in the Senonian sea urchin Echinocorys'.

The material was examined in groups, each one from a given horizon and locality, and in each group, breadth and height respectively were plotted against length on a logarithmic grid as described by J. S. Huxley ${ }^{2}$.

It was found that breadth was isometric ${ }^{3}$ relatively to-length, that is, it could be represented by the formula

$$
B=b^{\prime} \times L,
$$

where $b^{\prime}$, in the material examined, varied between approximately 0.8 and 0.9 .

Height, on the other hand, was represented by the simple allometry formula

$$
H=b \times L^{a},
$$

where the coefficient $\alpha$ was greater than unity, that is, height was positively allometric relatively to length, and the coefficient $b$ was smaller than unity, so that the ratio $H / L$ tended to be less than 1 .

On the whole, a large value for the coefficient $b$ was accompanied by a small value for the coefficient $\alpha$, and vice versa. The relationship between the two coefficients is expressed by a formula of the same type as Huxley's simple allometry formula, since the values, if plotted double-logarithmically, form approximately a linear figure.

There is some possibility that the changes in size and proportions can be correlated with changes in environment, that is, depth of water in the Chalk sea, in which case, an increase in size correlated with change of environment appears to give rise in many cases to a decrease in relative height, whereas a size increase in the ordinary course of the individual's growth gives rise to an increase.

A few sea urchins contemporary with Echinocorys were examined along similar lines, and although the material was scanty there was a suggestion that the coefficient $\alpha$ may be identical in contemporary of philosophy, a copy of which thesis is in the University library.

29 Mount Echo Drive,

Chingford, Essex.

${ }^{1}$ See Hayward, J. F., Naturalist (1941), for references.

"Huxley, J. S., "Problems of Relative Growth" (London, 1932).

s Needham, J., and Lerner, I. M., "Terminology of Relative Growth Rates", N $\triangle$ TURE, 146, 618 (1940).

\section{Expediting Visual Adaptation to Darkness}

THE problem of expediting artificially the adaptation of the eye to darkness is of considerable theoretical, and of no less practical importance, as, for example, in the case of night flying under war conditions. It has long been established that the period of adaptation when passing into complete darkness from a brilliantly lighted room is 45-50 minutes, and from a dully lighted room 25-30 minutes.

Proceeding from the theory of trophic adaptation of L. A. Orbeli, who demonstrated that the sense organs are innervated by the vegetative nervous system, I formulated the hypothesis that the process of adaptation to darkness is likewise influenced and controlled by the vegetative nervous system. The inflyence of this system on the visual apparatus (retina, conducting channels and brain centres) may be modified by exciting other sense organs by stimuli adequate to the latter. In $1937 \mathrm{I}$ experimented in expediting adaptation to darkness by exciting the organ of taste (with sugar), the effect of which was to shorten considerably the period of adaptation ${ }^{1}$.

Several months ago we experimented in expediting adaptation by means of light muscular exercise, during which the part of a weak exciter of the central nervous system and the visual organ is played by the nerve impulses imparted by the muscles and cartilages as they changed their length and thickness during muscular exercise.

Experiments made on ten subjects with the help of the adaptometer revealed that it was possible in this way to reduce the period of adaptation from 25-45 minutes to 5-6 minutes. Moreover, it was ascertained that usually sensitivity is roughly $20-30$ per cent higher after such exercises than after remaining 45 minutes in darkness in a state of rest. 